\title{
Pediatric Endoscopic Pilonidal Sinus Treatment (PEPSiT): Technical Description and Initial Experience
}

\section{Tratamento endoscópico pediátrico do seio pilonidal (PePSiT, em inglês): Descrição técnica e experiência inicial}

Carlos Ramon Silveira Mendes ${ }^{1,2}$ Luciano Santana de Miranda Ferreira1 ${ }^{10}$

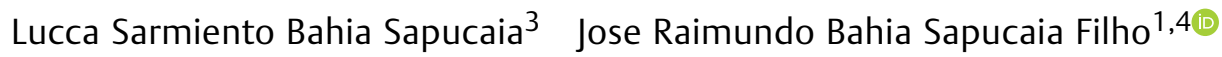

1 Sociedade Brasileira de Coloproctologia, Brazil

${ }^{2}$ Coloproctology Service, Hospital Geral Roberto Santos, Salvador, Bahia, Brazil

${ }^{3}$ Faculdade de Medicina, Universidade Salvador (UNIFACS), Salvador, Bahia, Brazil

${ }^{4}$ Associação Brasileira de Cirurgia Pediátrica, Brazil
Address for correspondence Carlos Ramon Silveira Mendes, Master, Serviço de Coloproctologia, Hospital Geral Roberto Santos, Rua Santa Izabela, 100, torre 1, apto. 1.002, Engenho Velho da Federação, Salvador, Bahia, Brazil (e-mail: proctoramon@hotmail.com).

J Coloproctol 2021;41(1):104-108.

\begin{abstract}
Pilonidal sinus is an acquired condition characterized by lesions at the median or paramedic intergluteal crease resulting form in grown hair at the subcutaneous, deep sacrococcygeal Keywords

- pilonidal sinus

- fistuloscope

- pilonidal disease

\section{Resumo \\ Palavras-chave \\ - cisto pilonidal \\ - fistuloscopio \\ - doença pilonidal}

O seio pilonidal é uma condição adquirida caracterizada por lesões na prega interglútea mediana ou paramédica, resultando em cabelo crescido na área subcutânea e profunda do sacrococcígeo. Vários métodos cirúrgicos foram descritos, o tratamento ideal do seio pilonidal permanece controverso. O estudo retrospectivo predefinido relata os resultados do tratamento endoscópico do seio pilonidal pediátrico em pacientes com menos de 18 anos de idade.
\end{abstract}

\section{Introduction}

Pilonidal sinus (PS) is an acquired condition characterized by lesions at the median or paramedian intergluteal crease resulting from ingrown hair at the subcutaneous, deep sacrococcygeal tissue. ${ }^{1}$ Recurrence of PS after the surgical treatment is very common, with a reported postexcision incidence of approximately $20 \%$ and high morbidity rates. received

July 21, 2020

accepted

August 30, 2020
DOI https://doi.org/

10.1055/s-0041-1726080.

ISSN 2237-9363.

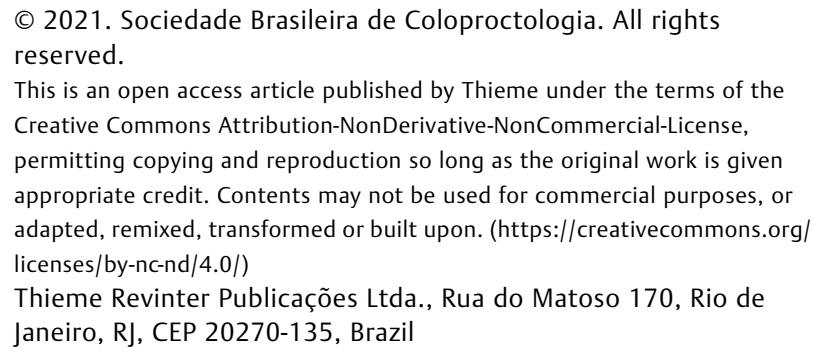

This is an open access article published by Thieme under the terms of the Creative Commons Attribution-NonDerivative-NonCommercial-License, permitting copying and reproduction so long as the original work is given appropriate credit. Contents may not be used for commercial purposes, or adapted, remixed, transformed or built upon. (https://creativecommons.org/ licenses/by-nc-nd/4.0/)

Thieme Revinter Publicações Ltda., Rua do Matoso 170, Rio de Janeiro, RJ, CEP 20270-135, Brazil 
While pediatric reports are scarce, PS is a common entity in children and adolescents, presenting rates of complication and recurrence similar to those observed in adults; in teenagers, its reported incidence is of $26: 100,000,2,3$ and there is a strong male preponderance. The increased prevalence of PS in early adolescence results from the increased production of sebum and hirsutism rates compared to those of younger children. ${ }^{1}$

Although multiple surgical methods have been described, the optimal PS treatment remains controversial. Conventional surgical approaches rely on the total excision of the sinus area, or sinus drainage with primary closure, marsupialization, or healing by second intention. Another possibility is simple hair removal from the affected region. Regardless of the performed treatment, pilonidal disease has a stable recurrence rate, ranging from $20 \%$ to $30 \%$. 4

In 2013, Meinero et al. ${ }^{6}$ described a new minimallyinvasive approach to PS, the endoscopic pilonidal sinus treatment (EPSiT), with promising outcomes, including faster wound healing and early return to work. In addition, these authors reported better pain control and better esthetic healing, with a recurrence rate lower than $10 \%$. Mendes et al. ${ }^{7}$ brought this technique to Brazil in 2014 and described similar outcomes.

The present retrospective study reports outcomes from the pediatric endoscopic pilonidal sinus treatment (PEPSiT), a minimally-invasive technique, in patients under 18 years old.

\section{Studied population}

The present is a retrospective sample analysis of 15 patients younger than 18 years of age (range: 6 to 14 years old) presenting recurring or non-recurring chronic pilonidal sinus disease who were submitted to PEPSiT from January to December 2018 in a single pediatric hospital. All patients received and signed a specific informed consent form describing the available alternatives, the technical details, and expected complications.

The inclusion criteria were patients younger than 18 years of age with pilonidal sinus disease accompanied by inflammation or abscess. The exclusion criteria were patients older than 18 years of age, immunocompromised subjects, and those whose parents' refused to sign the informed consent form.

\section{Surgical technique}

All procedures were performed under general anesthesia. The patient received a single dose of prophylactic antibiotic (cefazolin, $25 \mathrm{mg} / \mathrm{kg}$ ), and the skin was prepared with chlorhexidine. The PEPSiT procedure was performed according to the technique described by Meinero et al. ${ }^{6}$ and Mendes et al. ${ }^{8}$ The main sinus openings were removed by circular incision until a $0.5-\mathrm{cm}$ opening was available to place a pediatric cystoscope with an 8-Fr working channel (Karl Storz SE \& Co., Tuttlingen, Germany) (-Fig. 1). An infusion of containing $2 \%$ of mannitol or a glycine solution aided the cystoscopy and irrigated the pilonidal sinus (-Fig. 2). The pilonidal cavity was irrigated under high

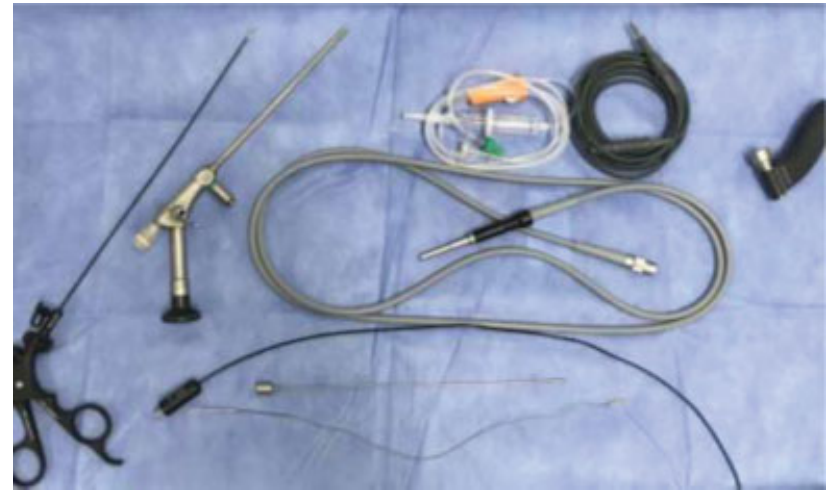

Fig. 1 Surgical equipment.

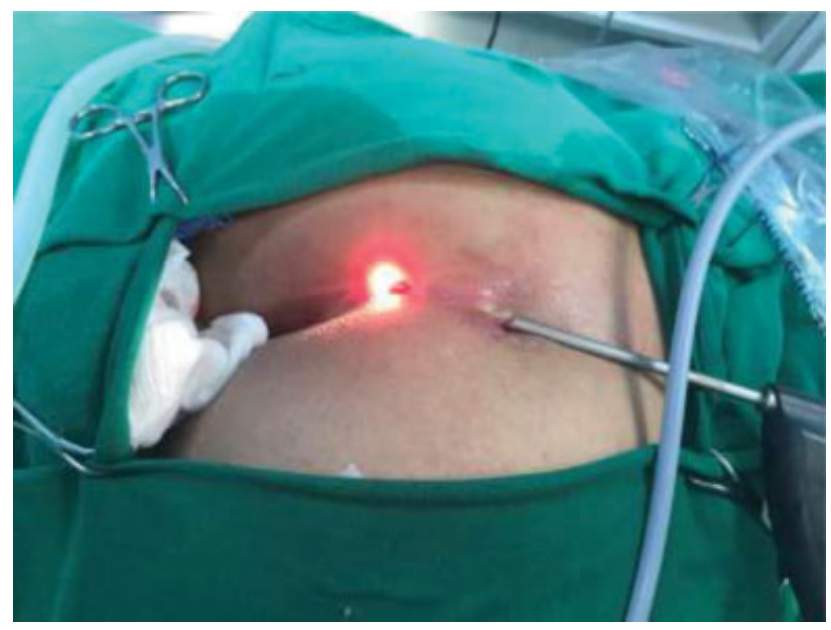

Fig. 2 Surgical procedure of the pediatric endoscopic pilonidal sinus treatment (PEPSiT).

pressure to increase its internal lumen and open its leaflets. This irrigation enabled the identification of all main and collateral openings, aiding the detection and removal of hair follicles and necrotic material under direct visualization (-Fig. 3). Then, a high-power electrocoagulation with

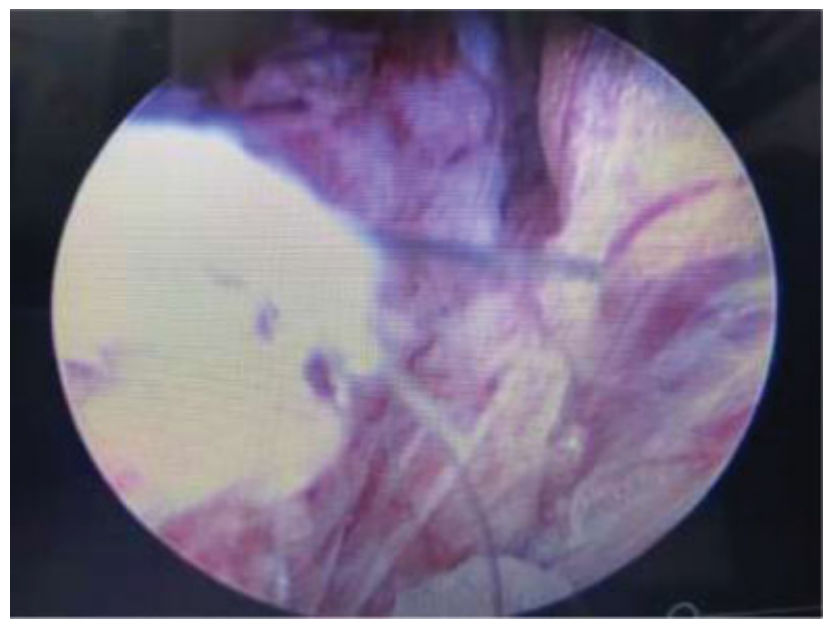

Fig. 3 Internal image of a pilonidal sinus. 
monopolar diathermy was performed under direct endoscopic view of the PS path. The PS cavity and any identified tracts were debrided with a disposable brush. Hemostasis was reviewed. At the end of the procedure, a compressive dressing was applied. All patients were admitted on the day of the surgery and discharged the next day. At discharge, they were instructed on daily dressing changes, local hygiene, and hair removal (through shaving, the use of hairremoval cream, or laser technology) after wound epithelization. Patients undergoing PEPSiT had no restrictions regarding daily activity.

\section{Postoperative care}

The postoperative evaluation was performed at the first week, fortnightly within the first month, and then every 3 months for one year after surgery. This evaluation was performed by the surgeon at an outpatient environment, starting at the first week after the procedure, until the complete healing of the wound. In addition, the patients were instructed to come promptly for an outpatient evaluation, at any time, if symptomatic. The healing time ranged from 40 to 64 days. The procedure was considered successful after complete wound closure, with no discharge, no pain at the surgical site (both spontaneously and during palpation), and no signs of infection/inflammation.

\section{Results}

In total, 15 patients , 11 males and 4 females aged between 6 and 14 years old, underwent the procedure. These subjects presented chronic infection at the pilonidal sinus and underwent the PEPSiT procedure.

The patients were placed in prone position and, under general anesthesia, the sinus drainage orifice was identified. A fistuloscope was passed to study the path of the sinus (-Fig. 1). Then, path curettage, hair removal, and hemostasis with electrocautery were performed. Complete healing of the external orifices occurred in a period ranging from 40 to 64 days, greatly improving postsurgical recovery.

After 1 year of follow-up, the recurrence rate was of $6.6 \%$. The technique was repeated in the affected patients with good outcomes.

\section{Discussion}

Pilonidal sinus is an inflammatory condition quite common in the pediatric population. Multiple techniques for the treatment of PS have been described during the last century, but its optimal therapeutic strategy has yet to be determined. In the past few decades, several published articles and reports on the trearment of pilonidal disease have addressed many available options, including primary midline repair, ${ }^{8,9}$ open healing, ${ }^{3}$ full-thickness lateral flaps, ${ }^{10}$ and epilation. ${ }^{11}$ The conventional surgical approaches are based on total excision of the PS area. Primary closure enables a faster wound healing, but is associated with a higher rate of wound-related complications, such as dehiscence, infection, and elevated recurrence rates. ${ }^{12,13}$ Some flap techniques were designed to place sutures outside the midline to reduce the complications, but they resulted in visible, complex scarring. ${ }^{14}$ All conventional methods showed considerably high recurrence rates due to the pathophysiology of PS. In addition, studies ${ }^{1,3}$ on the pediatric management of PS are limited mainly to retrospective reviews presenting outcomes and recommendations that are often contradictory.

In recent years, new minimally-invasive approaches to treat PS have emerged. In 2014, Meinero et al. ${ }^{6}$ described the EPSiT for adult patients. In 2018, Esposito et al. ${ }^{15}$ reported the first pediatric series with 15 patients submitted to the EPSiT for uninfected PS, demonstrating its feasibility and safety. The population of the present study is consistent with that of previous studies, since the median age in most reports is 16 years old, and the youngest patients are around 12 years old at the time of surgery. 3,16 In contrast to the findings from the adult population, some pediatric studies ${ }^{16}$ have similar rates for males and females. The small size of our series prevents us from obtaining results and complication rates that are more in line with those reported in the adult clinical practice. However, the postoperative outcomes of the present study are comparable to those reported by Meinero et al., ${ }^{6}$ with $94.8 \%$ of complete healing and $5 \%$ of recurrence, which validates our technical performance. Complete healing after the PEPSiT occurred after an average period of 1 month, which is consistent with the literature. ${ }^{13,17}$ The PEPSiT was performed as a short outpatient procedure or at a day-hospital regimen with a length of stay of 12 hours. Although most papers report relatively low rates of infection, there were virtually no infections in our PEPSiT series. However, all of our patients were submitted to antibiotic prophylaxis with cefazolin $(40 \mathrm{mg} / \mathrm{kg}$ until a maximum dose of $2 \mathrm{~g}$ ). Comparing different techniques, pediatric series present recurrence and reoperation rates of approximately $25 \%$ regardless of the procedure. $^{1,3,10}$ The PEPSiT is not inferior to total excision followed by primary closure regarding postoperative complications and disease recurrence. ${ }^{18}$ Furthermore, the PEPSiT has proven to be a viable and safe technique for reoperation, and must be encouraged in pediatric care. ${ }^{19}$ The present study is limited by the lack of comparison of our results with those from other commonly-performed techniques.

\section{Conclusions}

Considering the high morbidity rates related to most PS surgical approaches, the PEPSiT presented excellent outcomes in our series, consistent with those of the literature. Thus, we conclude that the PEPSiT represents a safe, reliable, effective, and versatile option for the treatment of pilonidal diseases.

Conflict of Interests

The authors have no conflict of interests to declare. 


\section{References}

1 Zagory JA, Golden J, Holoyda K, Demeter N, Nguyen NX. Excision and primary closure may be the better option in the surgical management of pilonidal disease in the pediatric population. Am Surg 2016;82(10):964-967

2 Yücesan S, Dindar H, Olcay I, et al. Prevalence of congenital abnormalities in Turkish school children. Eur J Epidemiol 1993; 9(04):373-380. Doi: 10.1007/BF00157393

3 Nasr A, Ein SH. A pediatric surgeon's 35-year experience with pilonidal disease in a Canadian children's hospital. Can J Surg 2011;54(01):39-42. Doi: 10.1503/cjs.028509

4 Braungart S, Powis M, Sutcliffe JR, Sugarman ID. Improving outcomes in pilonidal sinus disease. J Pediatr Surg 2016;51(02): 282-284

5 Arda IS, Güney LH, Sevmiş S, Hiçsönmez A. High body mass index as a possible risk factor for pilonidal sinus disease in adolescents. World J Surg 2005;29(04):469-471

6 Meinero P, Mori L, Gasloli G. Endoscopic pilonidal sinus treatment (E.P.Si.T.). Tech Coloproctol 2014;18(04):389-392. Doi: 10.1007/ s10151-013-1016-9

7 Mendes CRS, Ferreira LSM, Sapucaia RA, Lima MA. Endoscopic pilonidal sinus treatment (E.P.Si.T.): a minimally invasive approach. J Coloproctol (Rio J) 2015;35(01):72-75

8 Mendes CRS, Ferreira LSM, Sapucaia RA, Lima MA, Araujo SEA. VAAFT videoassited anal fistula treatment: a new approach for anal fistula. J Coloproctol (Rio J) 2014;34:62-64

9 Fike FB, Mortellaro VE, Juang D, Ostlie DJ, St Peter SD. Experience with pilonidal disease in children. J Surg Res 2011;170(01): 165-168

10 González-Temprano N, Sánchez-Vázquez M, Ayuso-González L, Pisón-Chacón J, Pérez-Martínez A. [Are we correctly treating pilonidal disease in children? therapeutic goals beyond preventing recurrence]. Cir Pediatr 2011;24(03):161-164
11 Al-Khamis A, McCallum I, King PM, Bruce J. Healing by primary versus secondary intention after surgical treatment for pilonidal sinus. Cochrane Database Syst Rev 2010;1(01):CD006213

12 Bütter A, Hanson M, VanHouwelingen L, Merritt N, Seabrook J. Hair epilation versus surgical excision as primary management of pilonidal disease in the pediatric population. Can J Surg 2015;58 (03):209-211

13 al-Hassan HK, Francis IM, Neglén P. Primary closure or secondary granulation after excision of pilonidal sinus? Acta Chir Scand 1990;156(10):695-699

14 Sharma PP. Multiple Z-plasty in pilonidal sinus-a new technique under local anesthesia. World J Surg 2006;30(12):2261-2265. Doi: 10.1007/s00268-005-0632-6

15 Esposito $\mathrm{C}$, Izzo S, Turrà $\mathrm{F}$, et al. Pediatric endoscopic pilonidal sinus treatment, a revolutionary technique to adopt in children with pilonidal sinus fistulas: our preliminar experience. J Laparoendosc Adv Surg Tech A 2018;28(03):359-363

16 Lee SL, Tejirian T, Abbas MA. Current management of adolescent pilonidal disease. J Pediatr Surg 2008;43(06):1124-1127. Doi: 10.1016/j.jpedsurg.2008.02.042

17 Yildiz T, Ilce Z, Kücük A. Modified Limberg flap technique in the treatment of pilonidal sinus disease in teenagers. J Pediatr Surg 2014;49(11):1610-1613. Doi: 10.1016/j.jpedsurg.2014.06.011

18 Sequeira JB, Coelho A, Marinho AS, Bonet B, Carvalho F, MoreiraPinto J. Endoscopic pilonidal sinus treatment versus total excision with primary closure for sacrococcygeal pilonidal sinus disease in the pediatric population. J Pediatr Surg 2018;53(10):2003-2007. Doi: 10.1016/j.jpedsurg.2018.02.094

19 Pini Prato A, Mazzola C, Mattioli G, et al. Preliminary report on endoscopic pilonidal sinus treatment in children: results of a multicentric series. Pediatr Surg Int 2018;34(06): 687-692. Doi: 10.1007/s00383-018-4262 0. Epub 2018 Apr 19 